\title{
An Economic Analysis of Changing Cropping Pattern in Almatti Command Area of Karnataka, India
}

\author{
Vinayak Jalikatti $^{1^{*}}$ and R.S. Poddar ${ }^{2}$ \\ ${ }^{1}$ Department of Agricultural Economics, UAS, Dharwad, India \\ ${ }^{2}$ WALMI, Dharwad, India
}

\section{Keywords}

Markov Chain, CAGR, Command area, Recommended cropping pattern

\section{Article Info}

Accepted:

10 September 2019

Available Online:

10 October 2019

\section{A B S T R A C T}

Almatti Left Bank Canal from Upper Krishna Project command area of the Karnataka state was selected for the purpose of analysing the changes in cropping pattern. The time series data on cropping pattern in selected canal command area were collected for a period of 10 years (2009-10 to 2018-19) and analysed using First Order Markov Chain Approach. In Almatti Left Bank Canal command area, maize crop was grown for fodder purpose while sunflower fetched high price and pearl millet was the main food in the command area. Hence, area under these crops remained stable. This indicates that the stability in the area under different crops in the study areas depends on availability of irrigation water, food and fodder requirement of the people and higher market price to the produce. In canal command the area under sorghum and groundnut was decreased, whereas area under sunflower has shown positive growth. The projected area under different crops in command area has shown a decreasing trend in case of maize and sunflower and increasing trend in case of sorghum and cotton. In Almatti command area, the higher deviation was found in Sugarcane (22.69\%) followed by Chilly (10.00\%), Cotton (9.71\%) and Sorghum $(8.75 \%)$. This study indicated that there was a violation in the cropping pattern from the recommended pattern in Almatti canal command area which was mainly due to farmers allocated more area under water intensive crops such as paddy and sugarcane. Hence, there is a need to bring the discipline among the farmers of the study

\section{Introduction}

Cropping pattern connotes the crop-mix grown in a particular area in an agricultural year. It determines the output mix in a particular region. Cropping pattern refers to adoption of particular type of crops by the farmers in a particular region. A change in cropping pattern implies a change in proportion of area under different crops. It has significant bearing on widening the geographical inequalities in income distribution. Introduction of new agriculture technologies has influenced the crop-mix which is more prominent in agriculture developed regions. A dynamic change has been witnessed in agriculture sector in our country, particularly during post-green revolution period. The technological advancement in crop varieties and other yield increasing factors of production influenced the farmers' behaviour which has reflected in the 
cropping pattern from cultivation of low value crops to high value crops in most of the regions.

The long-term changes in the cropping pattern in any region could be due to the development of irrigation infrastructure, whereas the vagaries of nature including rainfall and other institutional factors led to short term fluctuations in the cropped area as well as productivity. These short term and long term fluctuations have implications on the economic returns to the farmer as well as on the environment. To assess the extent and gravity of the consequences of such situation, knowledge of the dynamics of cropping pattern is essential. In addition to this Command Area Development Authority (CADA) recommends suitable cropping pattern for the command area on the basis of agro-climatic situation and availability of the water in the command area. This recommended cropping pattern needs to be follow by the farmers to increase crop productivity and also water productivity. Nowadays farmers are deviating from the recommended cropping pattern according to the market prices of different crops. Farmers cultivate such crops which fetch high market price irrespective of the recommended crops and agro-climatic conditions. Also lack of inspection by CADA officials, irregularity in water supply, unequal distribution of water in head middle and tail region are some of the major reasons for deviation in the cropping pattern. The present study aims to analyse the dynamics of copping pattern in Almatti canal command area with an objective to identify reasons for deviation in cropping pattern and to predict next three years cropping pattern in command area of Karnataka state.

\section{Materials and Methods}

The time series data pertaining to cropping pattern in the Almatti command area was collected for a period of 10 years (200910to2018-19) from offices of the Command Area Development Authority (CADA), Irrigation department and State Agriculture Departments.

\section{Tabular analysis}

It is used for the presentation of some of the data such as recommended and actual cropping pattern was studied by collecting the data from CADA, office. For this, ten years average area in per centage of existing cropping pattern under different crops was compared with the recommended cropping pattern and the deviation in the cropping pattern from the recommended patternwas worked out and presented in the form of tables.

\section{Compound growth rate analysis}

Growth of any variable indicates its past performance. The analysis of growth is usually used in economic studies to find out the trend of a particular variable over a period of time. It clearly indicates the performance of the variable under consideration and hence it can be very well used for making policy decisions. The growth in the area of different crops in the Command areas of Karnataka and its cropping pattern was estimated using the exponential growth function of the form:

$Y_{t}=a b_{t} u_{t}$

Where,

$Y_{t}$ : Dependent variable for which growth rate was estimated

a: Intercept

b: Regression coefficient

t: Years which takes values, 1, 2, ..,n

$\mathrm{Ut}$ : Error term for the year $\mathrm{t}$

The equation was transformed into log linear form for estimation purpose and was estimated 
using Ordinary Least Square (OLS) technique. The compound growth rate $(\mathrm{g})$ in per centage was then computed from the relationship,

$g=(\text { Antilog of } \ln b-1)^{*} 100$.

The significance of the regression coefficient was tested using the students ' $t$ ' test.

\section{Markov chain model}

The direction of change in cropping pattern was analysed by using First Order Markov Chain Approach. The Lingo Software was used for the purpose. Markov Chain Analysis is the estimation of the transitional probability matrix ' $\mathrm{P}$ ' whose elements, $\mathrm{P}_{\mathrm{ij}}$ indicate the probability of shifting area from one crop ' $i$ ' to another crop ' $\mathrm{j}$ ' over time. The diagonal element $\mathrm{P}_{\mathrm{ij}}$ where $\mathrm{i}=\mathrm{j}$, measures the probability of a crop retaining its share. The average area shifted to a particular crop was considered to be a random variable which depends only on the area under past crop, which can be denoted algebraically as:

$\mathrm{E}_{\mathrm{jt}}=\sum_{i=1}^{n}\left[E i_{t-1}\right] P_{i j}+e_{j t}$

Where,

$\mathrm{E}_{\mathrm{jt}}=$ Area of the crop shifted towards the particular $\mathrm{j}^{\text {th }}$ crop in the year $\mathrm{t}$

$\mathrm{Ei}_{\mathrm{t}-1}=$ Area lost by $\mathrm{i}^{\text {th }}$ crop during the year $\mathrm{t}-1$

$\mathrm{P}_{\mathrm{ij}}=$ the probability the area lost will shift from $i^{\text {th }}$ crop to $j^{\text {th }}$ crop

$\mathrm{e}_{\mathrm{jt}}=$ The error term which is statistically independent of $\mathrm{Ei}_{\mathrm{t}-1}$

$\mathrm{n}=$ the number of crops.

The transitional probabilities $\mathrm{P}_{\mathrm{ij}}$, which can be arranged in a ( $\mathrm{c} x \mathrm{n})$ matrix, have the following properties.

$$
\sum_{i=1}^{n} P_{I j}=1 \quad \text { And } 0 \leq \mathrm{P}_{\mathrm{Ij}} \leq 1
$$

Based on the results of Markov chain analysis, the Projections of area under different crops for the period (2019-2021) were made for all the canal Command areas by using:

$B_{t}=B_{0} x T$

$\mathrm{B}_{(\mathrm{t}+1)}=\mathrm{B}(\mathrm{t}+\mathrm{i}-1) \times \mathrm{T}$

Where

$\mathrm{B}_{0}=$ Area under the crop in base year;

$\mathrm{B}_{(\mathrm{t}+1)}=$ Area under the crop in next year (prediction);

$\mathrm{T}=$ Transitional probability matrix.

\section{Results and Discussion}

The Compound Annual Growth Rate (CAGR) of area under different crops in the command area is presented in Table 1. In Almatti Left Bank Canal the area under sorghum and groundnut was decreased annually at the rate of 12.57 per cent and 9.78 per cent respectively. Whereas area under sunflower has shown positive growth $(18.92 \%)$, but there was no significant change in area of other crops such as maize, wheat, pearl millet, cotton and onion.

The results of the transition probability matrix for major crops during kharif season Almatti command area are presented in Table 2. It is revealed from the table that, sorghum, wheat, maize, groundnut sunflower, pearl millet, onion, and cotton were the major kharif crops grown in ALBC. Among these major crops, the area under maize, sunflower, pearl millet and other crops was stable during the period. Sorghum and wheat crops lost 100 per cent area to other crops. While, maize crop lost 18 per cent, 42 per cent 4.1 per cent and 14 per cent of its area to maize, sunflower pearl millet onion and other crops, respectively. 
However, it gained 53 per cent 10 per cent 24 per cent, 100 per cent and 33 per cent area from sunflower, pearl millet onion, cotton and other crops, respectively during the 10 years period. Ground nut crop lost its entire previous year's area to pearl millet during the period. Sunflower had retained 45 per cent of its previous years' share of area and 53 per cent of its previous years' share to maize and 1 per cent to onion. At the same time, it gained 18 per cent area from maize and 72 per cent area from onion. Pearl millet retained 32 per cent of its previous years' share of area and lost 10 per cent area to maize, 0.2 per cent to onion and about 56 per cent to other crops. However, it gained 42 per cent of area from maize, 100 per cent from groundnut, 2.60 per cent from onion and 22 per cent from other crops. Onion had not retained any previous years' area and lost 24 per cent area to maize, 72 per cent to sunflower and 2.60 per cent to pearl millet crops. However, it gained 4.10 per cent area from maize, 1 per cent from sunflower and 0.2 per cent from pearl millet. Cotton crop lost 100 per cent of its previous year's area to maize and retained 0.70 per cent area from other crops. The area under other crops was stable and lost about 33 per cent and 22 per cent area to maize and pearl millet crops while gained 100 per cent area from sorghum and wheat, 14 per cent from maize and 56 per cent from pearl millet crops.

The maize crop was grown exclusively for fodder purpose while sunflower fetch high price and pearl millet was the staple food in the command area. Hence, area under these crops remained stable in the command area.

Structural changes in rabi cropping pattern over the last 10 years period in Almatti command area are presented in Table 3. It is observed from the transitional probability matrix that, sorghum, sunflower and other $r a b i$ crops were the stable crops in ALBC during last 10 years' period. Since sorghum is main food crop in the ALBC, rabi sorghum emerged as the most stable crop and occupied 98 per cent area in ALBC while sorghum lost 6.7 per cent area of its previous year area to wheat, 1.7 per cent to maize, and 32 per cent to groundnut. Wheat lost 15 per cent area to maize, 82 per cent to other crops and at the same time gained 6.7 per cent area from sorghum, 57 per cent from maize and 31 per cent from other crops. Area under maize crop was also unstable in the study period. Maize has lost 57 per cent area to wheat, 32 per cent to onion and 9.8 per cent to cotton.

Table.1 Compound growth rates for area under different crops in Almatti command area of Karnataka

\begin{tabular}{|c|l|c|}
\hline SI. No & \multicolumn{1}{|c|}{ Crops } & ALBC \\
\hline $\mathbf{1}$ & Sorghum & $-12.57^{* * *}$ \\
\hline $\mathbf{2}$ & Maize & $0.84^{\mathrm{NS}}$ \\
\hline $\mathbf{3}$ & Wheat & $0.80^{\mathrm{NS}}$ \\
\hline $\mathbf{4}$ & Pearl millet & $-2.06^{\mathrm{NS}}$ \\
\hline $\mathbf{5}$ & Groundnut & $-9.78^{* * *}$ \\
\hline $\mathbf{6}$ & Sunflower & $18.92^{* *}$ \\
\hline $\mathbf{7}$ & Cotton & $6.80^{\mathrm{NS}}$ \\
\hline $\mathbf{8}$ & Onion & $6.35^{\mathrm{NS}}$ \\
\hline $\mathbf{9}$ & Others & $-0.93^{\mathrm{NS}}$ \\
\hline
\end{tabular}

Note: 1. ***, **, * denotes significance at $1 \%, 5 \%$ and $10 \%$ level respectively 2. Other crops include Red gram, Caster and Niger. 
Table.2 Transition probability matrix for different crops in Almatti during kharif season

\begin{tabular}{|l|c|l|l|l|l|l|l|l|l|}
\hline Crops & Sorghum & Wheat & Maize & Groundnut & Sun flower & $\begin{array}{l}\text { Pearl } \\
\text { millet }\end{array}$ & Onion & Cotton & Others \\
\hline Sorghum & $\mathbf{0 . 0 0 0}$ & 0.000 & 0.000 & 0.000 & 0.000 & 0.000 & 0.000 & 0.000 & 1.000 \\
\hline Wheat & 0.000 & $\mathbf{0 . 0 0 0}$ & 0.000 & 0.000 & 0.000 & 0.000 & 0.000 & 0.000 & 1.000 \\
\hline Maize & 0.000 & 0.000 & $\mathbf{0 . 2 1 0}$ & 0.000 & 0.180 & 0.420 & 0.041 & 0.000 & 0.140 \\
\hline Ground nut & 0.000 & 0.000 & 0.000 & $\mathbf{0 . 0 0 0}$ & 0.000 & 1.000 & 0.000 & 0.000 & 0.000 \\
\hline Sunflower & 0.000 & 0.000 & 0.530 & 0.000 & $\mathbf{0 . 4 5 0}$ & 0.000 & 0.010 & 0.000 & 0.000 \\
\hline Pearl millet & 0.000 & 0.000 & 0.100 & 0.000 & 0.000 & $\mathbf{0 . 3 2 0}$ & 0.002 & 0.000 & 0.560 \\
\hline Onion & 0.000 & 0.000 & 0.240 & 0.000 & 0.720 & 0.026 & $\mathbf{0 . 0 0 0}$ & 0.000 & 0.000 \\
\hline Cotton & 0.000 & 0.000 & 1.000 & 0.000 & 0.000 & 0.000 & 0.000 & $\mathbf{0 . 0 0 0}$ & 0.000 \\
\hline Others & 0.000 & 0.000 & 0.330 & 0.000 & 0.000 & 0.220 & 0.000 & 0.007 & $\mathbf{0 . 4 3 0}$ \\
\hline
\end{tabular}

Table.3 Transition probability matrix for different crops in Almatti during rabi season

\begin{tabular}{|l|c|c|c|c|c|c|c|c|c|}
\hline Crops & Sorghum & Wheat & Maize & Ground nut & Sunflower & $\begin{array}{c}\text { Pearl } \\
\text { millet }\end{array}$ & Onion & Cotton & Others \\
\hline Sorghum & $\mathbf{0 . 5 9 0}$ & 0.067 & 0.017 & 0.320 & 0.000 & 0.000 & 0.000 & 0.000 & 0.000 \\
\hline Wheat & 0.000 & $\mathbf{0 . 0 0 0}$ & 0.150 & 0.000 & 0.000 & 0.000 & 0.002 & 0.000 & 0.820 \\
\hline Maize & 0.000 & 0.570 & $\mathbf{0 . 0 0 0}$ & 0.000 & 0.000 & 0.000 & 0.320 & 0.098 & 0.000 \\
\hline Ground nut & 0.980 & 0.000 & 0.015 & $\mathbf{0 . 0 0 0}$ & 0.000 & 0.000 & 0.000 & 0.000 & 0.000 \\
\hline Sunflower & 0.000 & 0.000 & 0.000 & 0.000 & $\mathbf{0 . 4 2 0}$ & 0.000 & 0.000 & 0.000 & 0.570 \\
\hline Pearl millet & 0.000 & 0.000 & 0.000 & 0.590 & 0.250 & $\mathbf{0 . 0 0 0}$ & 0.000 & 0.140 & 0.000 \\
\hline Onion & 0.000 & 0.000 & 0.000 & 0.000 & 0.000 & 0.000 & $\mathbf{0 . 0 0 0}$ & 0.000 & 1.000 \\
\hline Cotton & 0.000 & 0.000 & 0.000 & 0.000 & 0.000 & 0.000 & 0.000 & $\mathbf{0 . 0 0 0}$ & 1.000 \\
\hline Others & 0.000 & 0.310 & 0.000 & 0.130 & 0.034 & 0.000 & 0.053 & 0.000 & $\mathbf{0 . 4 6 0}$ \\
\hline
\end{tabular}


Table.4 Projected area under different crops in Almatti Command area (Kharif)

(Acres)

\begin{tabular}{|c|c|c|c|c|c|c|}
\hline Year & Maize & Sun flower & Pearl millet & Onion & Cotton & Others \\
\hline 2019 & $\begin{array}{l}1918.64 \\
(26.44)\end{array}$ & $\begin{array}{l}820.64 \\
(11.31)\end{array}$ & $\begin{array}{c}1990.98 \\
(27.44)\end{array}$ & $\begin{array}{l}93.70 \\
(1.29)\end{array}$ & $\begin{array}{c}16.94 \\
(0.26)\end{array}$ & $\begin{array}{c}2414.99 \\
(33.28)\end{array}$ \\
\hline 2020 & $\begin{array}{c}1873.33 \\
(26.16)\end{array}$ & $\begin{array}{l}782.11 \\
(10.92)\end{array}$ & $\begin{array}{c}1976.68 \\
(27.60)\end{array}$ & $\begin{array}{c}90.85 \\
(1.27)\end{array}$ & $\begin{array}{c}16.90 \\
(0.26)\end{array}$ & $\begin{array}{c}2422.00 \\
(33.82)\end{array}$ \\
\hline 2021 & $\begin{array}{l}1843.56 \\
(26.08)\end{array}$ & $\begin{array}{l}754.56 \\
(10.67)\end{array}$ & $\begin{array}{c}1954.54 \\
(27.65)\end{array}$ & $\begin{array}{l}88.58 \\
(1.25)\end{array}$ & $\begin{array}{c}16.95 \\
(0.26)\end{array}$ & $\begin{array}{c}2410.67 \\
(34.10)\end{array}$ \\
\hline
\end{tabular}

Note: Figures in parenthesis indicates per centages

Table.5 Projected area under different crops in Almatti Command area (Rabi)

(Acres)

\begin{tabular}{|c|c|c|c|c|c|c|c|c|}
\hline Year & Sorghum & Wheat & Maize & Ground nut & Sun flower & Onion & Cotton & Others \\
\hline $\mathbf{2 0 1 9}$ & 2310.05 & 912.27 & 202.78 & 958.56 & 154.16 & 174.86 & 18.16 & 2165.80 \\
& $(33.50)$ & $(13.23)$ & $(2.94)$ & $(13.90)$ & $(2.24)$ & $(2.54)$ & $(0.29)$ & $(31.40)$ \\
\hline $\mathbf{2 0 2 0}$ & 2302.32 & 941.76 & 190.49 & 1020.77 & 138.38 & 181.50 & 19.87 & 2025.22 \\
& $(33.76)$ & $(13.81)$ & $(2.79)$ & $(14.97)$ & $(2.03)$ & $(2.66)$ & $(0.32)$ & $(29.69)$ \\
\hline $\mathbf{2 0 2 1}$ & 2358.73 & 890.65 & 195.71 & 1000.02 & 126.98 & 170.18 & 18.67 & 1984.09 \\
& $(34.97)$ & $(13.20)$ & $(2.90)$ & $(14.83)$ & $(1.88)$ & $(2.52)$ & $(0.30)$ & $(29.42)$ \\
\hline
\end{tabular}

Note: Figures in parenthesis indicates per centages 
Table.6 Recommended and actual cropping pattern in Almatti Command areas of Karnataka

\begin{tabular}{|c|l|c|c|c|}
\hline SI. No. & \multicolumn{1}{|c|}{ Crop } & Recommended area & \multicolumn{2}{|c|}{ UKP } \\
\cline { 4 - 5 } & & $(\mathbf{\%})$ & Actual Area (\%) & Deviation (\%) \\
\hline $\mathbf{1}$ & Maize & 10.00 & 10.08 & 0.08 \\
\hline $\mathbf{2}$ & Ground nut & 15.00 & 7.59 & -7.41 \\
\hline $\mathbf{3}$ & Pearl millet & 10.00 & 2.65 & -7.35 \\
\hline $\mathbf{4}$ & Sun flower & 10.00 & 3.19 & -6.81 \\
\hline $\mathbf{5}$ & Green gram & 5.00 & 10.54 & 5.54 \\
\hline $\mathbf{6}$ & Red gram & 2.50 & 11.20 & 8.70 \\
\hline $\mathbf{7}$ & Chick pea & 5.00 & 8.40 & 3.40 \\
\hline $\mathbf{8}$ & Sorghum & 10.00 & 18.75 & 8.75 \\
\hline $\mathbf{9}$ & Wheat & 10.00 & 4.62 & -5.38 \\
\hline $\mathbf{1 0}$ & Chilly & 10.00 & 0.00 & -10.00 \\
\hline $\mathbf{1 1}$ & Cotton & 10.00 & 0.29 & -9.71 \\
\hline $\mathbf{1 2}$ & Sugarcane & 0.00 & 22.69 & 22.69 \\
\hline $\mathbf{1 3}$ & Horticulture crops & 2.50 & 0.00 & -2.50 \\
\hline
\end{tabular}

Groundnut crop lost 98 per cent area to sorghum and 1.5 per cent to maize. And gained about 32 per cent area from sorghum and 59 per cent and 13 per cent from pearl millet and other crops respectively. The area under sunflower crop was stable and at the same time lost about 57 per cent of its previous years' area to other crops, however gained about 25 per cent and 3.4 per cent from pearl millet and other crops, respectively. Pearl millet had lost about 59 per cent, 25 per cent and 14 per cent area to ground nut, sunflower and cotton, respectively.

Onion crop lost its 100per cent area to other crops while gained about 32 per cent and 5.3 per cent area from maize and other crops, respectively. Cotton lost its entire area to other crops while gained 9.8 per cent and 14 per cent area from maize and pearl millet crops, respectively. The area under other crops was also stable during the period and they lost 31 per cent, 13 per cent, 3.4 per cent and 5.3 per cent area to wheat, groundnut, sunflower and onion crops, respectively.
However, other corps gained 82 per cent area from wheat, 57 per cent from sunflower and 100 per cent area from onion and cotton.

Area projections of different crops in Almatti command area

The area projections of major crops grown in Almatti command area of Karnataka was computed based on the transitional probability matrix and projections were made up to 2021 (Table 4 and 5). The projected area under different crops in Almatti command area shown a decreasing trend in case of maize and sunflower and increasing trend in case of sorghum and cotton. While in case of pearl millet, onion wheat and maize the projected area would remain constant.

\section{Recommended and actual cropping pattern in Almatti command area}

The data pertaining to crops grown during last 10 years was collected from CADA office. Ten years average percentage area under different crops was compared with 
recommended cropping pattern in Almatti command area to study the deviation of existing cropping pattern from the recommended cropping pattern. The crops suggested in the localised pattern of Almatti command area were 10 per cent each under Maize, Pearl millet, Sunflower, Sorghum Wheat Chilly and Cotton, 15 per cent under Groundnut, 5 per cent each under Green gram and Chickpea and 2.5 per cent each under Red gram and Horticulture crops. However, the actual area in percentage of ten years average was 10.08 per cent under Maize, 2.65 per cent under Pearl millet, 3.19 per cent under Sunflower, 18.75 per cent under Sorghum, 4.62 per cent under Wheat, zero per cent under Chilly, 0.29 per cent under Cotton, 7.59 per cent under Groundnut, 10.54 per cent under Green gram, 8.40 per cent under Chickpea, 11.20 per cent Red gram and zero per cent under Horticulture crops. The higher deviation was found in Sugarcane $(22.69 \%)$ followed by Chilly (10.00\%), Cotton $(9.71 \%)$ and Sorghum (8.75\%) (Table 7).

It is concluded that, in Almatti command area, maize crop was only grown for fodder purpose while sunflower fetched high price and pearl millet was the main food in the command area. Hence, area under these crops remained stable. The projected area under different crops in Almatti command area has shown a decreasing trend in case of maize and sunflower and increasing trend in case of sorghum and cotton. In Almatti command area the higher deviation against the recommended was seen in Sugarcane, Chilly, Cotton, and Sorghum. This study indicated that there was a deviation in the cropping pattern from the recommended pattern in
Almatti canal command area which was mainly due to farmers allocating more area under water intensive crops such as paddy and sugarcane. Hence, there is a need to bring the discipline among the farmers of the study area through proper training and guidance in order to make them not only in strictly following the recommended cropping pattern but also in the optimum use of water.

\section{References}

Arvinda, K. and H. Basavaraja, 2010, Changes in cropping pattern in northern transitional zone of Karnataka. Agric. Situ. India, 67(8): 447-453.

Ashwini B.C. and Kiresur V.R., 2017, Dynamics of cropping pattern in Mandya district of Karnataka, Journal of Farm Sciences, 30(2), 222-225.

Goswami, S.N., Dubey, P.N. and Challa, O. (2003). Land use dynamics in Mizoram, Agric. Situ. India, 60(8): 531 - 538.

Harish, M.H., 2006, An economic appraisal of land use dynamics in Mandya district. M.Sc. (Agri.) Thesis, Univ. Agric. Sci., Dharwad, Karnataka (India).

Rao Dayakar and ShahidParwez, 2005, Dynamics of cropping pattern in sorghum growing states of India. Indian J. Agric. Econ., 60(4): 644 -659.

Sreeja, M., 2004, Land use dynamics in Kerala- an economic analysis. M.Sc. (Agri) Thesis, Univ. Agric. Sci., Dharwad (India).

Wali, V. S., R. S. Poddar, S. M. Mundinamani and B. S. Yenagi, 2019, An analysis of cropping pattern in Malaprabha project command area, Int. J of Agric. Sci. 11(2), 7739-7742.

\section{How to cite this article:}

Vinayak Jalikatti and Poddar, R.S. 2019. An Economic Analysis of Changing Cropping Pattern in Almatti Command Area of Karnataka. Int.J.Curr.Microbiol.App.Sci. 8(10): 1052-1059. doi: https://doi.org/10.20546/ijcmas.2019.810.123 